\title{
PELATIHAN ROBOTIKA BERBASIS ANDROID UNTUK MENUMBUHKAN INOVASI DAN KREATIVITAS DI SMP 11 BANDUNG
}

\author{
Aceng Sambas, Mujiarto, Gugun Gundara, Shofiatul Ula \\ Prodi Teknik Mesin, Fakultas Teknik, Universitas Muhammadiyah Tasikmalaya \\ acengs@umtas.ac.id
}

DOI : 10.31604/jpm.v2i1.8-12

\begin{abstract}
The development of the world of science and technology is developing very rapidly especially in the field of robotics automation technology. Robotics is an automation technology that has been developed in various scientific disciplines such as the automotive, education, arts, health, agriculture, farm, fisheries, marine, mining, nuclear reactors, military missions and space explorers. This study aims to create an arduino robot that is controlled using android. The training was attended by class X students at SMP 11 Bandung.. The initial study of this research was to design a Proteus simulation to test the performance of robots. Next, design the robot by combining the motor driver, wheel engine and Arduino. Finally, integrate the robot with Android to control the robot's navigation system. This Android-based Arduino robot training will be introduced to students in the robotics workshop at SMP 11 Bandung as a medium for teaching physics or electronics. With this training, it is expected that students will be able to increase innovation and more creativity towards the subjects taught.
\end{abstract}

Keywords: robotic, arduino, android.

\begin{abstract}
Abstrak
Perkembangan sains dan teknologi dunia berkembang sangat cepat terlebih dibidang teknologi otomasi robotika. Robotika merupakan teknologi otomatisasi yang telah dikembangkan dalam berbagai disiplin ilmu seperti industri otomotif, pendidikan, kesenian, kesehatan, pertanian, peternakan, perikanan, kelautan, pertambangan, reaktor nuklir, misi militer dan penjelajah ruang angkasa. Penelitian ini bertujuan untuk membuat sebuah robot arduino yang dikendalikan menggunakan android. Pelatihan ini dihadiri oleh siswa kelas X di SMP 11 Bandung. Studi awal penelitian ini adalah membuat perancangan simulasi Proteus untuk menguji kinerja robot. Selanjutnya, rancang bangun robot dengan menggabungkan motor driver, mesin roda dan arduino. Terakhir, mengintegrasikan robot dengan Android untuk pengontrolan sistem navigasi robot. Pelatihan robot arduino berbasis android ini akan dikenalkan pada siswa pada kegiatan workshop robotik di SMP 11 Bandung sebagai media alat peraga pelajaran fisika atau elektronika. Dengan adanya pelatihan ini diharapkan siswa mampu meningkan inovasi dan kreatifitas lebih terhadap mata pelajaran yang diampu.
\end{abstract}

Kata kunci: robot, arduino, android.

MARTABE : Jurnal Pengabdian Masyarakat $\mid 8$ 


\section{PENDAHULUAN}

\section{Analisis Situasi}

Teknologi kini sudah menjadi sebuah kemajuan dalam memudahkan pekerjaan umat manusia. Seperti handphone yang digunakan untuk komunikasi, Televisi untuk menyampaikan berita. Komputer untuk pengolahan data dan mesin cerdas untuk menyelesaikan permasalahan dalam dunia kerja yang kita sebut dengan robot (Sanjaya, 2014). Pada dasarnya robot adalah sebuah device elektronik maupun mekanik yang bertujuan untuk membantu pekerjaan manusia. Dalam kasus tertentu, memungkinkan manusia berada dalam kondisi bahaya, maka pada kondisi ini robot sangat efektif untuk digunakan. Selain itu, robot dapat diprogram sesuai perintah user karena dilengkapi perangkat mesin yang kompleks (Budiharto, 2006; Sanjaya 2016).

Beberapa studi terkait robot telah intensif diteliti oleh para ilmuan. Dalam bidang kesehatan, robot bedah digunakan untuk prosedur medis invasif (Smith dkk, 2019). Dalam bidang pertanian organik, robot digunakan untuk deteksi gulma. Dengan bantuan vision, aktuator mekanik robot bergerak untuk menghilangkan tanaman gulma (Sellmann dkk, 2014). Selain itu, robot memiliki peranan penting dalam bidang pendidikan anak berkebutuhan khusus seperti autism. Pada kasus ini, robot digunakan sebagai media terapi dan membantu mendorong keterampilan interaksi sosial pada anak (Robins dkk, 2005; Dautenhahn dan Werry, 2000; Fujimoto dkk, 2011).

Teknologi ini semakin berkembang karena kebutuhan dunia industri akan peralatan robotika yang dapat meningkatkan produksi. Untuk mendukung dunia industri sudah sepatutnya dunia pendidikan ikut serta mendukung kemajuan teknologi tersebut. Dukungan di dunia pendidikan dilakukan dengan mempersiapkan tenaga kerja yang dapat terjun ke dunia industri dan memahami teknologi robot (Febri, 2015).
Proses pendidikan yang dilakukan sekarang ini terbentur suatu masalah akan minimnya ketersediaan alat ajar/peraga. Perkembangan teknologi robot tidak didukung dengan perkembangan ketersediaan alat ajar/peraga yang dibutuhkan dalam pendidikan robotika. Selain karena minimnya ketersediaan pasar juga diakibatkan oleh mahalnya harga alatalat ini untuk dibeli secara utuh. Di Indonesia belum banyak toko yang bisa menyediakan alat-alat peraga untuk kepentingan pendidikan robotika.

Berdasarkan situasi di atas, kami mengusulkan sebuah pelatihan robotika berbasis kontrol android yang digunakan sebagai alat peraga pendidikan dalam elektronika. Selain itu, siswa dapat mengeluarkan keterampilan terbaiknya dalam membuat sebuah perancangan pekerjaan dan menyelesaikan permasalahan yang dihadapi. Ini sangat memungkin siswa untuk mengekspresikan kreativitas mereka. Dengan pelatihan ini, siswa diharapkan dapat membangun hubungan antara siswa dan robot, dan mendorong tren pembelajaran anak menjadi lebih baik. Hasil ini menunjukkan bahwa ke depan penggunaan teknologi robot dapat digunakan untuk intervensi pendidikan jangka-panjang pada anak-anak yang lebih muda.

\section{Permasalahan Mitra dan Penentuan Prioritas Masalah}

Beberapa permasalahan dalam pelatihan rancang bangun robot berbasis android adalah pada penyediaan bahan dan keterbatasan biaya. Bahan-bahan robotik yang ada di toko sangat mahal sehingga banyak para pengembang pendidikan robotik menyerah dengan situasi seperti ini.

Banyak para komunitas yang mengembangkan pendidikan melalui Lego dalam pengembangan bidang robotik. Hal ini menyebabkan banyak ketergantungan tanpa dapat mengembangkan baik dalam desain maupun program. Selain itu, jika kita ingin mengembangkan level 
selanjutnya maka kita perlu membeli Lego sehingga mitra kesulitan

\section{Solusi yang Ditawarkan}

Solusi kami dalam mengatasi permasalahan di atas, salah satunya menambahkan komponen yang diperlukan oleh robot dengan komponen mainan yang sering dijumpai dalam kehidupan seharihari. Selain itu, bahan-bahan yang kami gunakan dalam pelatihan robotik ini yaitu bahan bekas yang dapat digunakan dalam perancangan robot sehingga dapat membuat robot dengan harga terjangkau.

Selanjutnya, kami membuat modul tutorial perancangan Robot yang dikendalikan menggunakan android. Tahap pertama dengan menampilkan landasan teori Robot berbasis android. Tahap kedua, membuat simulasi robot berbasis android menggunakan software Proteus. Terakhir, rancang bangun robot berbasis android.

\section{METODE PELAKSANAAN}

Metode pelaksanaan yang digunakan pengabdian ini mengacu pada pemberian pelatihan keterampilan perakitan robotika di SMP 11 Bandung. Adapun tahapan pelaksanaan kegiatan disajikan pada Gambar 1.

\section{HASIL DAN PEMBAHASAN}

\section{Pelaksanaan Kegiatan}

Tahap pertama kegiatan ini adalah siswa diberi pengarahan tentang sistem kerja robot yang terdiri dari tiga bagian yaitu masukan sistem, proses dan output yang diinginkan. Setelah itu, kami memberikan penjelasan tentang penggunaan software proteus dan arduino. Software proteus digunakan untuk membuat skema dari robot sedangkan software arduino digunakan untuk membuat program untuk mengontrol robot menggunakan smartphone.

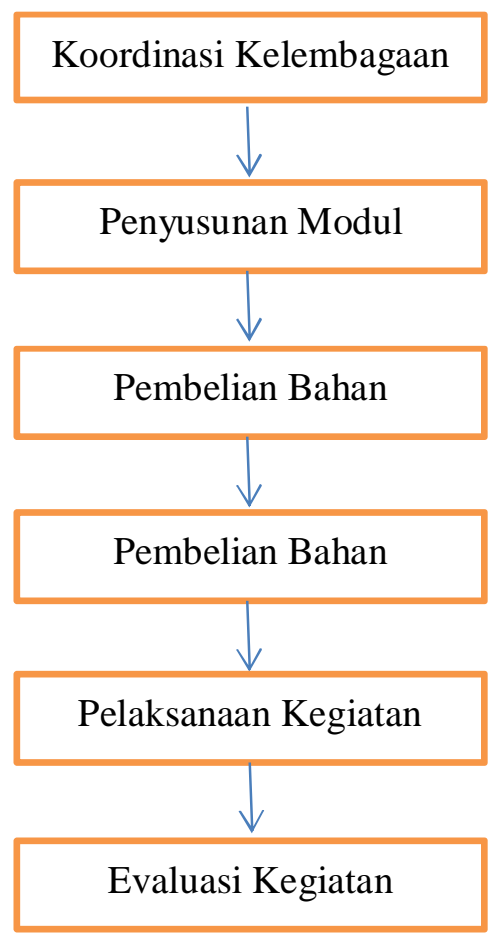

Gambar 1: Pelaksanaan Kegiatan

Selanjutnya, kami telah menyediakan bahan-bahan robot yang terdiri dari tiga komponen utama. Pertama adalah motor DC sebagai aktuator dari robot dan akrilik digunakan sebagai kaki dari robot. Kedua motor driver L293D yang berguna untuk memberikan perintah pada motor DC dan ketiga adalah bluetooth yang berguna untuk menghubungkan smartphone dengan arduiono.

Robotika merupakan salah satu media untuk menumbuhkan kemampuan siswa dalam berpikir kritis, problem solving, kreatif, inovatif, dan kerjasama dalam tim. Hal ini sangat diperlukan dalam membangun sebuah robot. Dengan adanya kerja sama tim pekerjaan akan menjadi lebih mudah dan ringan. Keahlian siswa saat merakit robot dan membuat program dengan software arduino terlihat selama pembelajaran sehingga seluruh siswa dapat mengikuti materi dengan sangat baik. Pelaksanaan kegiatan dapat dilihat pada Gambar 2. 

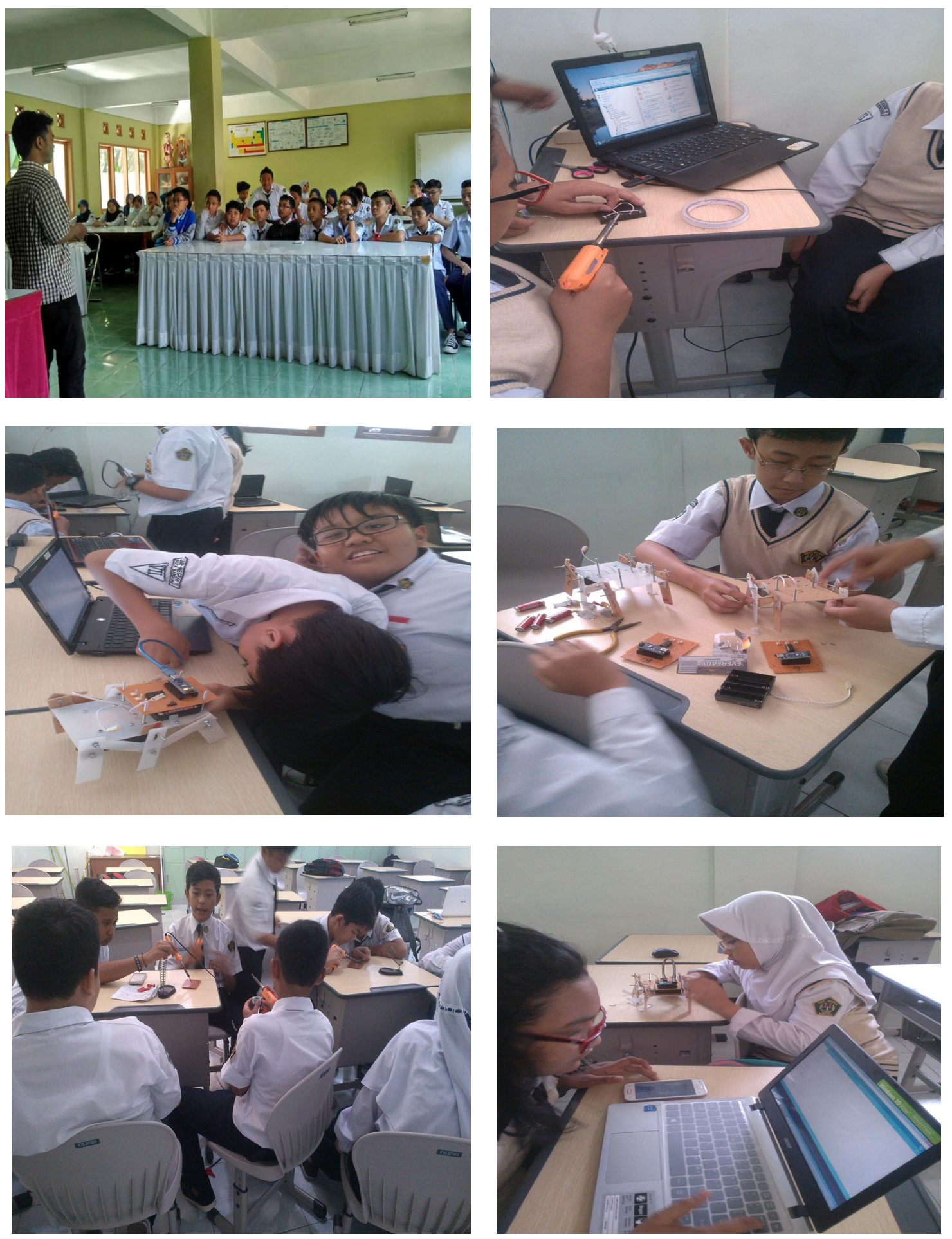

Gambar 2: Kegiatan pelatihan robotika di SMP 11 Bandung 
Aceng Sambas, dkk. Pelatihan Robotika Berbasis Android Untuk Menumbuhkan ...

\section{Hambatan Kegiatan Pengabdian Masyarakat Dan Solusi}

Pelaksanaan kegiatan pengabdian masyarakat ini terkendala dengan waktu sehingga masih ada beberapa materi dasar yang perlu disampaikan kepada siswa. Kegiatan ini dilaksanakan hanya satu hari saja. Kedepannya diharapkan untuk mengagendakan waktu yang lebih baik lagi.

\section{KESIMPULAN}

Pengembangan pelatihan robotika berbasis android pada siswa SMP 11 Bandung dapat berjalan dengan baik. Hal ini terlihat dari antusias siswa dalam mengikuti kegiatan ini. Dengan adanya pelatihan robot ini siswa mendapatkan dampak positif untuk meningkatkan kreativitas dan inovasi.

\section{UCAPAN TERIMA KASIH}

Terima kasih disampaikan kepada Universitas Muhammadiyah Tasikmalaya yang telah mendanai kegiatan pengabdian ini.

\section{DAFTAR PUSTAKA}

Asri, Y. N. (2018). Pembelajaran berbasis stem melalui pelatihan robotika. Jurnal Wahana Pendidikan Fisika, 3(2), 74-78

Budiharto, W., (2006), Belajar Sendiri: Membuat Robot Cerdas. Jakarta: Elex Media Komputindo.

Dautenhahn, K., dan Werry, I. (2000). Issues of robot-human interaction dynamics in the rehabilitation of children with autism. Proc. From animals to animats, 6, 519-528.

Febri, C. P. (2015). Servo Kontroler Sepagai Penggerak Kaki Robot
Dengan Komunikasi Serial Berbasis Mikrokontroler Atmega 16 (Doctoral dissertation, UNY).

Robins, B., Dautenhahn, K., Te Boekhorst, R., dan Billard, A. (2005). Robotic assistants in therapy and education of children with autism: can a small humanoid robot help encourage social interaction skills?. Universal Access in the Information Society, 4(2), 105-120.

Sanjaya, W. S. M., (2014). Panduan Praktis Pemrograman Robot Vision Menggunakan Matlab dan IDE Arduino, Yogyakarta: Penerbit Andi.

Sanjaya, W. S. M., (2016), Membuat Robot Cerdas Berbasis Speech Recognition Menggunakan MATLAB dan Arduino, Yogyakarta: Penerbit Andi.

Sellmann, F., Bangert, W., Grzonka, S., Hänsel, M., Haug, S., Kielhorn, A., Michaels, A., Möller, K., Rahe, F., Strothmann, W dan Trautz, D. (2014). RemoteFarming. 1: Humanmachine interaction for a fieldrobot-based weed control application in organic farming. In 4th International Conference on Machine Control \& Guidance, March (pp. 19-20).

Smith, D. W., DeSanctis-Smith, R., Pitt, A. M., Theodore, N., dan Crawford, N. (2019). U.S. Patent Application No. 16/111,559.

Fujimoto, I., Matsumoto, T., De Silva, P. R. S., Kobayashi, M., \& Higashi, M. (2011). Mimicking and evaluating human motion to improve the imitation skill of children with autism through a robot. International Journal of Social Robotics, 3(4), 349-357. 